\title{
Scenario of Terror: Royal Violence and the Origins of Russian Tragic Drama*
}

\author{
Kirill Ospovat
}

Tragedy as a literary genre and theatrical form was introduced to Russia around 1750 by the 'Russian Racine', Aleksandr Sumarokov (1717-1777), a poet, dramatist, and stage director active at the courts of Empresses Elizabeth (r. 1741-1761) and Catherine II (r. 1762-1796). In Petersburg, as in other European capitals, theatrical performances at court were a central element of what Richard Wortman in his standard study of Russian political symbolism defines as 'an ongoing theater of power.' Since the late 1730s, and especially after the ascension of Elizabeth in 1741, Western-type court theater gradually set foot in Russia, as foreign (French, Italian, and German) companies were hired or invited to perform at court. ${ }^{2}$ This was the background for the emergence of Russian-language theater officially established under Sumarokov's directorate by a royal decree of $175^{6}$. As David M. Lang remarks, 'In establishing the St Petersburg theater, Sumarokov and his collaborators Volkov and Dmitrievsky had to contend with a task even more formidable than that which had confronted Gottsched in Germany twenty years earlier. The only means of ensuring the continued patronage of the Empress Elisabeth, whose encouragement and financial support

* This paper is a part of a study carried out within the project 'Early Modern European Drama and the Cultural Net' at the Freie Universität Berlin, funded by the European Research Council.

1 Richard Wortman, Scenarios of Power: Myth and Ceremony in Russian Monarchy (Princeton: Princeton University Press, 1995), vol. 1, pp. 3-4.

2 On Sumarokov see Marcus Levitt, 'Sumarokov: Life and Works', in Marcus Levitt, Early Modern Russian Letters: Texts and Contexts (Boston: Academic Studies Press, 2009), 6-21, and other essays in this volume. On the early history of Russian court theater, see V.N. VsevolodskiiGerngross, Teatrv Rossii pri imperatritse Elizavete Petrovne (Saint-Petersburg: Giperion, 2003); F.G. Volkov i russkii teatr ego vremeni. Sbornik dokumentov (Moscow: Izd-vo AN SSSR, 1953); L.M. Starikova (ed.), Teatral'naia zhizn' Rossii v epokhu ... Elizavety Petrovny ... Dokumental'naia khronika, Vol. 2/1 (Moscow: Nauka, 2003); Vol. 2/2, (Moscow: Nauka, 2005); Vol. 3/1 (Moscow: Nauka, 2011). 
were indispensable, was to compose dramas in Russian which could compare favourably with those acted by the rival Italian and French troupes.. ${ }^{3}$

Tragedy was the central genre of Russian-language court theater and $\mathrm{Su}-$ marokov's dramatic oeuvre. V.N. Vsevolodskii-Gerngross stresses that throughout the eighteenth century, Russian tragedy was both poorly performed and poorly received outside the capitals, where it was 'cultivated by the Russian aristocracy', a limited social group centered around the court and more adequately identifiable as the 'court society', or the political class of servitors. He concludes that Russian classicist tragedy was specifically tailored to negotiate 'the problematic relationship between the aristocracy and the monarchy'. ${ }^{4}$ Aligning this argument with current discussions of the intrinsic affinity between tragedy and monarchy in early modern Europe, my paper will explore the ways in which this perspective allows for a new approach to eighteenthcentury Russian drama on the one hand, and the Russian autocracy, on the other. Focusing on Russia's first classicist tragedy, Aleksandr Sumarokov's Khorev (1747), I will examine its deeply ambiguous representation of monarchy,

3 David M. Lang, 'Sumarokov's Hamlet: A Misjudged Russian Tragedy of the Eighteenth Century', Modern Language Review 43 (1948), 67-72, esp. p. 69. The first attempt to import Western tragedy into Russia was undertaken in 1672 by Elizabeth's grandfather, Tsar Aleksei, who ordered the Moscow Protestant pastor Johann Gottfried Gregorii to prepare a stage version of the Book of Esther. The ensuing play, Artakserksovo deistvo (The Comedy of Artoxerxes), extant both in the German original and Russian stage version, is a typical Trauerspiel centered around the figure of the king, or tsar, as biblical rulers were known in Russia. This play inaugurated a tradition of Russian-language dramatic texts, political and religious in matter, which served as scripts for sporadic amateur performances at court or in Latin schools, in the absence of an established practice of neo-Latin drama. In the early eighteenth century the corpus of dramatic texts in Russian was amplified by translations of plays from the repertory of the German wandering troupes, among them Andreas Gryphius's Papinian und Lohenstein's Sophonisbe. This tradition provides an important and underestimated background for Sumarokov's classicist reform which aimed to supplant it.

V.N. Vsevolodskii-Gerngross, 'Politicheskie idei russkoi klassitsisticheskoi tragedii', in O teatre. Sbornik statei (Leningrad; Moscow: Iskusstvo 1940), pp. 107-109; G.A. Gukovskii, Russkaia literatura XVIII veka [Moscow: Gos. uchebno-pedagogicheskogo izd-vo, 1939], Moscow 1998, p. 135. For a valuable discussion of the political and historical underpinnings of Sumarokov's tragedies see E.A. Kasatkina, 'Sumarokovskaia tragediia 40-kh-nachala $5^{0}$-kh godov XVIII veka', Uchenye zapiski Tomskogo pedagogicheskogo instituta XIII (1955), 213-261. On the 'political dialogue' between eighteenth-century Russian rulers and the elites, reflected in the literary production of the time, including plays, see Cynthia H. Whittaker, Russian Monarchy: Eighteenth-Century Rulers and Writers in Political Dialogue, (DeKalb: Northern Illinois University, 2003). 
shaped by the fundamental tensions inherent both in absolutist concepts of sovereignty and in tragedy as a genre of court theater which evoked grief in order to celebrate the status quo.

\section{Poetry, History, Allegory}

In his famous study of early modern tragic drama (Trauerspiel) Walter Benjamin concludes that

Historical life, as it was conceived at that time, is its content, its true object. In this it is different from [ancient] tragedy. For the object of the latter is not history but myth, and the tragic stature of the dramatis personae does not derive from rank — the absolute monarchy—but from the pre-historic epoch of their existence - the past age of heroes. For Opitz (...) it is (...) the confirmation of princely virtues, the depiction of princely vices, the insight into diplomacy and the manipulation of all the political schemes, which makes the monarch the main character in the Trauerspiel. The sovereign, the principal exponent of history, almost serves as its incarnation. (...) The image of the setting or, more precisely, of the court, becomes the key to historical understanding. For the court is the setting par excellence. ${ }^{5}$

Sumarokov's dramatic poetics (contemporaneous to the beginnings of Russian secular historiography) depended on a similar appropriation of the 'tragic' fascination for 'the past age of heroes' by absolutist political imagination. Most of his tragedies, long recognized as political in substance and always set in royal residences populated by 'tsars, princes and magnates', 6 treat historical, or mythistorical, subjects from Russia's past. Khorev, in particular, builds upon a historical legend. According to ancient chronicles, the medieval Russian capital Kiev was founded by Kii, who ruled there as the oldest of three brothers, among them Khorev. Except for the foundation of Kiev and a military raid on Byzantium (characteristic for the first generations of historical Russian rulers), no details of the brothers' actions are reported. Using this scarce data as his starting point, Sumarokov devised a complex dramatic plot.

5 Walter Benjamin, The Origin of the German Tragic Drama, transl. by John Osborne (London and New York: Verso, 1985), pp. 62, 92.

6 Gukovskii, Russkaia literatura XviII veka, p. 135. 
In his version, Kii had conquered Kiev from its previous ruler, Zavlokh, whose infant daughter, Osnelda, was captured and grew up in Kiev as a prisoner of war. Sixteen years later, Zavlokh is back at Kiev's walls demanding nothing but the release Osnelda. She is passionately loved by Khorev, Kii's much younger brother and heir, and reciprocates his feelings. Together the lovers forge a plan to arrange their marriage which would end all hostilities and reunite the nation. Kii's counselor Stalverkh, having got wind of the young couple's secret accord but not knowing its exact purpose, relates to Kii his suspicion of a conspiracy possibly planned by the popular Khorev to overthrow the elderly ruler with the help of Zavlokh and his troops. Kii is enraged with Stalverkh's report of his secret dealings and sends Khorev into battle with Zavlokh to restore his hitherto unblemished 'glory'. Osnelda receives a letter from Zavlokh forbidding her marriage to Khorev, and burns it on the spot in desperation. Having learned of the secret correspondence, Kii summons Osnelda, accuses her of political conspiracy, and sentences her to death by poison. Khorev returns triumphant, bringing Zavlokh as his prisoner. Finally convinced in his innocence, Kii tries to repeal Osnelda's death sentence, but it is too late. Stalverkh off stage and Khorev on stage commit suicide, while Kii and Zavlokh regret their cruelty towards the young lovers. ${ }^{7}$

It might seem a paradox that for the first time introducing to Russia a markedly 'foreign' literary form - a French-type five-act neoclassical tragedy, strictly observing the notorious unities and written in German-sounding alexandrine metric couplets of iambic hexameter, a meter almost non-existent in Russia before Sumarokov-he chose national history for his subject, in an apparent contradiction to the canonical pattern of French classicist tragedy that Sumarokov wished to import to Russia. Apparently, Sumarokov's dramatic experiments were informed by an aesthetic which mapped visions of sovereignty onto the national historical lore, producing a dramatic idiom which could easily oscillate between historicist distance and topical allusion, narra-

7 Scholarship on Khorev refers without exception to the abridged and revised version of play published by Sumarokov in 1768 and reproduced in the posthumous Polnoe sobranie vsekh sochinenii and in all subsequent printings. This is also the text translated by Richard and Raymond Fortune in Sumarokov's Selected Tragedies (Evanston: Northwestern University Press 1970). I will refer to the original 1747 version: Aleksandr Sumarokov, Khorev. Tragediia (Saint-Petersburg: Pri Akademii nauk, 1747), citing the page number in parenthesis. When possible I will use the Fortunes' English text with necessary emendations, also citing the page numbers. 
tives of progress and reenactments of the monarchy's primeval violence. With its ambiguous referentiality, history provided a suitable discursive cast for the unspeakable horrors of the state of exception which lay at the origins of tragic drama and monarchy itself. ${ }^{8}$

The relationship between drama and national history was addressed, among others, by Pierre Brumoy, a leading authority on ancient theater and an influential representative of the French classicist criticism which dominated literary thinking in eighteenth-century Russia. In his comparison of ancient Greek and contemporary French tragedy, attached to his widely read Théâtre des Grecs (1730) he complained that, while both the Greeks and the French took dramatic subjects from history or 'popular traditions, which are living annals', the French tragedy

borrows its materials from abroad; and very seldom takes them from the history of our own country. (...) As to the antiquity of our monarchy, the grandeur of our most remarkable events, and the exploits of our heroes, they are subjects that give us pleasure in history: they are naturally interesting to us from the love we bear to our native country: but whether it is that our vanity startles at seeing truths in pure theatrical pieces, assume the appearances of fables (...) we are not easily reconciled to domestic themes upon our theatre.

The Greeks, on the contrary, drew upon 'history or the fables of their own country' which 'were to them inexhaustible, nay, their only funds', so that 'there is not a city, a festival, nor a monument among the Grecians, which was not celebrated by one or more theatrical entertainments.'9

Brumoy's influential remarks provide an important background for some of the subsequent attempts to adapt episodes from national history for the uses of tragedy: as if to make up for the deficiencies he described, the original patriotic functions of the genre could be revived and adapted to the monarchical

8 On tragic drama and the state of exception see Carl Schmitt, Political Theology: Four Chapters on the Concept of Sovereignty, transl. by George Schwab (Cambridge, MA: Harvard, 1985); Benjamin, The Origin of the German Tragic Drama; Louis Marin, 'Théâtralité et pouvoir: Magie, machination, machine: Médée de Corneille', in id., Politiques de la représentation (Paris: Editions Kimé, 2005), pp. 275-285; Samuel Weber, 'Taking Exception to Decision: Walter Benjamin and Carl Schmitt', Diacritics 22, 3/4, (Autumn-Winter, 1992), 5-18.

9 The Greek Theatre of Father Brumoy (London: Mess. Millar a.o., 1759), vol. 1, pp. ciii-civ; cf. Pierre Brumoy, Théâtre des Grecs, vol. 1 (Paris: Lottin, 1785), pp. 183-185. [I found a first edition $1732]$. 
sentiment of modern polities. The German dramatist Johann Elias Schlegel (1719-1749) published in the 1740s two 'national' tragedies: Hermann (1743), and Canut (1746). Canut, which only preceded Sumarokov's dramatic debut by a year, provides a striking parallel to his experiments in tragedy, as it was written in Denmark in a conscious effort to inaugurate a local 'national' theater under court patronage. The play focuses on a medieval king whose considerable military and political achievement made him a ready national paragon for successful royal rule.

Sumarokov's dramatizations of early Russian history follow a similar pattern. Bringing to the stage a legendary forefather and giving him the anachronistic title of 'the prince of Russia' ('kniaz' Rossiskii', 4), he constructs his drama as a medium for the commemoration of a national past identified with royal history, 'the antiquity of our monarchy'. Similar to the Greeks who composed their tragedies in celebration of national events and sites, Sumarokov chooses as his setting the ancient capital associated with the beginnings of a unified Russian monarchy and its adoption of Christianity.

The festive resonance of this choice must have been evident in 1747. Three years earlier, in 1744, a year and a half after her ascent to the throne, Empress Elizabeth undertook a trip to Kiev, obviously laden with political symbolism as the ensuing ceremonial events and official publications duly reveal. One of the principal sites visited by the Empress was the Kievan Academy, a churchrun institution of classical learning whose cultural importance far outgrew the confines of what was by then a depopulated provincial town. Sermons delivered by the Academy's teachers (and later published in Petersburg, the actual imperial center) outlined the continuous tradition of royal power that linked Elizabeth to the medieval rulers of Kiev, and pageantry was employed to convey a similar message. As one source reports,

The Kievan academy with the help of imported and locally designed machinery presented the Empress with various curious shows for her pleasure; among other things, out of the city came a grave old man of the most ancient age, magnificently decorated and invested with a crown and staff, represented by a young student. His chariot was a divine phaeton driven by a pair of poetic winged steeds named Pegasus, chosen from robust students. The old man signified the ancient founder and prince of Kiev, Kii. He met the Empress on the bank of Dnepr, at the end of the bridge, welcomed her with a solemn speech and, calling her his heiress, invited into the city as his dominion, and surrendered it and the whole Russian people to her gracious protection. During the banquets prepared for the Empress by the estates and the people of Little Russia with the 
most vivid sentiments of genuine zeal and boundless joy, the Empress said once amidst innumerable people: 'I wish, oh Lord, you would love me as much in the heavenly kingdom as I love this well-minded and gentle people!'10

Kievan students staged a royalist version of national memory, using theatrics to revive the vital link between the current political order and its original point of constitution. Sumarokov's Khorev, conceived both as a work of literature worthy to be printed and enter the emerging national canon and as a script for court productions, did not only adopt the central figure of Kii but developed and explored the symbolic and poetic effects aimed for by the ceremonial performance.

The figure of Kii, however naïvely schematic it might appear both in the masque and in the tragedy, points towards a set of issues fundamental for early modern dramatic treatments of history. Aristotelian doctrine-readily available to Sumarokov in André Dacier's annotated translation of the Poetics into French, and to the Kievan scholars in Feofan Prokopovich's De arte poetica (ca. 1705) - framed the discussion of dramatic plot by a seemingly clear-cut but in fact complex distinction between 'poetry' and 'history' as fiction and nonfiction: 'an Historian writes what did happen, and a Poet what might, or ought to have come to pass (...) Poetry (...) treats of general, and History relates only particular things.'11 This distinction is immediately complicated in Aristotle's argument by an ambiguous notion of the 'received legends' ('known Fables', in eighteenth-century English), which serve as possible sources for tragic plots and, more importantly, provide a paradigm of oscillation between truth and fiction. The classical scholar Brumoy draws on Aristotelian language when he refuses to distinguish between the two in his definition of the national memory of the Greeks as 'history or the fables of their own country'.

The bulk of actual historical lore available to a dramatist, whether ancient or modern, is not confined by the strict Aristotelian definition of 'history' but equally pertains to 'poetry'. This was acknowledged in the emerging Russian historiography (a discourse quite relevant for Sumarokov, as his own historical essays confirm). Vasilii Tatishchev, who was circulating the first manuscript

10 'Istoriia Russov', Chteniia v Obshchestve istorii i drevnostei rossiiskikh, 1846, № 4, otd. 2, p. 244.

11 Aristotle's Art of Poetry: Translated from the Original Greek ... Together with Mr. D'Acier's notes from the French (London: D. Browne and W. Turner, 1705), pp. 137-138; La Poétique d'Aristote traduite en françois avec des remarques critiques ... par André Dacier (Paris, 1692, repr. Hildesheim: Olms, 1976), pp. 131-133. 
copies of his History of Russia, a monumental compilation of Russian medieval chronicles, around the same time as Sumarokov was writing his first historical dramas, faithfully reproduced medieval origin legends but flouted at the evident falsehoods propagated by the annalistic tradition, sarcastically comparing early chroniclers to classical epic authors, standard examples of poetic fiction. One of the evident cases in point was the story of Kii, reported by Tatishchev and immediately denounced in a separate note as fictitious. ${ }^{12}$ The producers of the Kievan masque, professionally versed in classical idiom, conveyed a similar message by entrusting Kii's chariot to 'a pair of poetic winged steeds named Pegasus'.

If history is itself 'poetry', then tragedy as defined by Aristotle provides a paradigm for its proper reading. In Dacier's terms, Aristotle suggests a poetics of tragedy which is 'neither Historical nor Particular, but General and Allegorical'. Indeed, the interpretation of Aristotle outlined here clearly resonates with Benjamin's important conclusion that in early modern drama 'a series of types such as is formed by king, courtier, and fool, has an allegorical significance.'13 This is precisely the function that Kii, in fact nothing more than a name, could easily assume both in the masque and the tragedy. Far from disturbing the logic of festive representation with historical particulars, he served as an allegory of royal power and monarchical political order. It was the allegorical generalization behind the name that resonated with Elizabeth's enthusiastic protestations of mutual love between her and her subjects during the Kievan festivities, and, later, with the voice of Sumarokov's Kii (II, 1): 'Vladychestvo moe liubov'iu utverzhdeno' (18; 'My sov'reignty in love stands steadfast without challenge', 54). Consequently, Sumarokov's play represents what Rüdiger Campe calls 'the theater of institution', a dramatic analysis of the monarchy's archetypical features. ${ }^{14}$

12 V.N. Tatishchev, 'Istoriia rossiiskaia', in id., Sobranie sochinenii, vol. 2 (Moscow: Ladomir, 1995), 30; vol. 4, (Moscow: Ladomir 1994), pp. 110, 391.

13 Aristotle's Art of Poetry, pp. 146-147; La Poétique d'Aristote, p. 141; Benjamin, The Origin of German Tragic Drama, p. 191; Jane K. Brown, The Persistence of Allegory: Drama and Neoclassicism from Shakespeare to Wagner (Philadelphia: University of Pennsylvania Press, 2007).

14 Rüdiger Campe, 'Theater der Institution: Gryphius' Trauerspiele Leo Armenius, Catharina von Georgien, Carolus Stuardus und Papinianus', in R. Galle, R. Behrens (eds.), Konfigurationen der Macht in der Frühen Neuzeit (Heidelberg: Winter 200o), pp. 257-287. 


\section{The Tragedy of Suspicion}

Set in ancient Kiev and featuring Kii as its royal protagonist, Khorev is a 'tragedy of origins' in John D. Lyons's terms, a conceptually charged representation of the monarchy's foundational structures. ${ }^{15}$ Ilya Serman has suggested that Sumarokov's depiction of his characters was dependent on the prevalent conceptualizations of historical developments in general and the primeval origins of royal power in particular. ${ }^{16}$ Indeed, Russia's history-centered around Riurik, the medieval founder of the Russian state, and his progeny who ruled Russia for seven hundred years - was the history of an unquestionably absolute monarchy. A mid-eighteenth-century memoirist who generally focused on contemporary court politics and military operations, made a short digression to report that 'the government of Russia was always despotic' and that 'the respect felt by the Russian people for the descendants of the first Grand Duke Riurik was so high that they were far from any thoughts of even the slightest rebellion until his race lasted, and no one probably ever thought that Russia could be ruled otherwise than by a despotic ruler.'17 Tatishchev, both in the History of Russia and in the pamphlet against aristocratic limitations on monarchy, used accounts of ancient Russian history to corroborate his unconditional support for absolute royal rule and viewed them as an antidote against such 'harmful' books as Machiavelli's The Prince, Hobbes's Leviathan, and others, which had lead some 'perfidious magnates' to unleash the 'Leviathan' of aristocratic faction in $1730 .{ }^{18}$ As Tatishchev's line of reasoning demonstrates, historical knowledge evoked to support the absolutist dogma implied and perpetuated the possibility of dissent and revolt it was meant to contain. This was recognized by the authorities: as Evgenii Anisimov shows, any public reference to Russia's past rulers or historical events could be interpreted as sedition by the secret police. Among the crimes imputed to Artemii Volynskii in 1740 was the fact that he and his companions used to read chronicles and history works and to draw parallels between political situations past and present. ${ }^{19}$

15 John D. Lyons, The Tragedy of Origins: Pierre Corneille and Historical Perspective (Stanford: Stanford University Press, 1996).

16 I.Z. Serman, Russkii klassitsizm: Poeziya, Drama, Satira (Leningrad: Nauka, 1972), pp. 122 sqq.

17 Perevoroty i voiny (Moscow: Fond Sergeia Dubova, 1997), pp. 268-269.

18 Tatishchev, 'Istoriia rossiiskaia', in Sobranie sochinenii, v. 1, pp. 86-89, 359, 362, 368; id., 'Proizvol'noe i soglasnoe rassuzhdenie i mnenie sobravshegosia shliakhetstva russkogo o pravlenii gosudarstvennom', in Sobranie sochinenii, v. 8 (Moskva: Ladomir) 1996, p. 148.

19 E.V. Anisimov, Dyba i knut. Politicheskii sysk i russkoe obshchestvo v XVIII veke (Moskva: 
Sumarokov's representation of Russian history was shaped by similar issues. Besieged in Kiev by a contender he had once himself ousted by force and questioning the loyalty of his subjects including his own brother, Sumarokov's Kii finds himself in a position characteristic of medieval Russian politics and dynastic chronicles. At the same time his position allows for a theoretical inquiry into the foundations and stability of royal rule, an issue central both for political practice and readings of history in mid-eighteenth-century Russia. If the play's exposition in the first act is dominated by Khorev's and Osnelda's pastoral musings, the second act introduces us to the sinister world of court politics. It opens with a scene of council between Kii and his 'first boyar' Stalverkh who questions the honesty of Zavlokh's promise to withdraw from Kiev once he receives Osnelda, and warns Kii against his own subjects (II, 1): 'Bregisia, gosudar', nechaiannykh izmen' (19; 'Beware, my prince, before unlooked-for treachery', 53). Kii at first seems unwilling to share this fears:

Что может, рассуди, изменник учинить?
Народ бесчисленный удобно ль возмутить,
В котором множество мне сердцем покоренно?
Владычество мое любовью утвержденно,
Меня мои раби непринужденно чтят,
Мне верности давно их внутренну явят.

18

(Consider and reflect; what can the traitor do?

Can he cause to rebel a nation numberless,

Whose hearts unto my rule with faithfulness are humbled?

My sov'reignty in love stands steadfast without challenge.

My followers are true and give me their respect.

Through many years they showed to me their inner selves.)

54

Kii's speech, however, suggests a situation much less serene than it claims and than parallels with court pageantry would seem to imply. In April 1742, soon after Elizabeth's ascension to the throne as a result of a palace revolution, the French diplomat and the Empress's close confidant Jacques-Joachim Trotti, marquis de La Chétardie had to assure his superiors in Paris that la

Novoe literaturnoe obozrenie, 1999), pp. 58-62; Aleksei Tolochko, 'Istoriia Rossiiskaia' Vasiliia Tatishcheva, (Moskva: Novoe literaturnoe obozrenie, 2005). 
force de ses droits et l'amour de ses peuples la rassurent au point d' envisager l' avenir avec autant de tranquillité que si elle était montée sur le trône sans révolution' ('the force of her rights and the love of her peoples reassure her so much that she can look forward with so much tranquility as if she had ascended the throne without a revolution') ${ }^{20}$ Chétardie's wording is characteristic of the political language evoked to make sense of the complex and shifting political circumstances in Petersburg, the language of Machiavelli's The Prince. $^{21}$

As Tatishchev's remarks indicate, Machiavelli's work was already well known in Russia, and could be directly associated with the dangers of revolt. Focusing on practical techniques of empowerment, The Prince acknowledged and even endorsed the possibility of acquiring supreme authority through conquest and usurpation but provided the contenders for power with clear-sighted advice:

I say then, that it is a much easier matter to support an hereditary State, which has been long accustomed to obey the family of a Prince that reigns over it, than such a one as has been newly acquired (...) But in the government of a Principality newly-acquired, many difficulties occur. (...) as most men are ready enough to change their rulers, in expectation of bettering their condition, such a persuasion induces them to take up arms against their Governors (...) The most effectual preservative then against conspiracies, is not to be hated and despised by the people (...). ${ }^{22}$

In his account of Elizabeth's coup Chétardie revives-while attempting to obliterate-Machiavelli's distinction between the two types of domination, old and new; a similar attempt frames the position of Kii, who is simultaneously an 'old' ruler (he has reigned over Kiev for sixteen years) and a 'new' one (he had conquered it by force). Machiavelli's description of the popular craving for upheavals fostered by frequent changes of power seemed to provide an optimal explanation for the Russian tumults of 1740-1741, with Elizabeth overthrowing Anna Leopoldovna only a year after Anna herself had in a similar fashion seized power from the omnipotent regent Johann Biron with the help of the influen-

20 Sbornik Imperatorskago Russkogo istoricheskogo obshchestva, vol. 100 (Saint-Petersburg 1897), 148.

21 On the reception of Machiavelli in eighteenth-century Russia, see a very informative source study: M.A. Iusim, Makiavelliv Rossii: Moral' i politika na protiazhenii piati stoletii, (Moscow: Institut vseobshchei Istorii RAN, 1998), pp. 77-186. 
tial general Burchard von Münnich. It was said that Münnich deserved to be punished if only 'for having first shown a dangerous example of overthrowing princes and raising them to the throne with a company of grenadiers.' ${ }^{23}$ Frederick II, an informed if biased observer and an attentive reader of Machiavelli, commented in his Histoire de mon temps on Russian court politics of the time:

Such enterprises, which would appear rash in other governments, may sometimes be accomplished in Russia. The national spirit is inclined to revolt. The Russians, in common with other people, are dissatisfied with the present and hope better from the future. ${ }^{24}$

A Machiavellian vision of popular instincts fundamentally challenged the conception of Russians as a people particularly devoted to its despotic monarchs, suggested by conventional readings of national history. This tension, negotiated in Tatishchev's juxtaposition of his loyalist historiography to the seditious Machiavelli, is again reenacted in Kii's lines quoted above: entangled in a rhetorical figure, he wishes to assert the fidelity of his subjects but ends up questioning it. Confronted with Stalverkh's allegations against Khorev, he attempts to dismiss them but cannot help admitting that the need to question appearances is inherent in the position of a ruler (II, 1):

Сталверх! Ты верен мне, но дело таково

Восходит выше сил понятья моего.

Кому на свете сем вдруг верити возможно? [...]

Хочу равно и ложь и истину внимать

И слепо никого не буду осуждать.

Мятусь, и лютого злодея видя в горе.

Князь-кормщик корабля, власть княжеская-море,

Где ветры, камни, мель препятствуют судам,

Желающим пристать к покойным берегам.

Но часто кажутся и облаки горами,

Летая вдалеке по небу над водами,

Которых кормщику не должно обегать;

Но горы ль то иль нет, искусством разбирать.

23 Perevoroty i voiny, p. 477.

24 Frederick II, 'History of my Own Times', in Posthumous Works of Frederic II King of Prussia, transl. from the French by Thomas Holcroft, vol. 1 (London: G.G.J. and J. Robinson, 1789), p. 170 . 
Хоть все б вещали мне, там горы, мели тамо,

Когда не вижу сам, плыву без страха прямо.

20-21

(You have been true to me, Stalverkh, but such a thing

Beyond my understanding far exceeds the bounds.

Who dwells upon the earth whose word can now be trusted?

If I could but believe both falsehood and the truth

That I might not be forced dishearted to condemn! [...]

I am perplexed to see in grief even a villain.

The prince pilots the ship; his power is the ocean,

Where winds and rocks and shoals obstruct the passing boats,

Whose only goal is this: to reach a tranquil shore.

But sometimes even clouds appear to us as mountains,

Drifting through distant skies above the churning waters,

Which he, the helmsman, must discern to guide his ship,

Distinguishing with skill the mountain from the cloud.

And though the world should shout: 'There lie the rock and shallows!'

If I discern them not, I sail on fearing nothing.)

$55^{-56}$

In Levitt's words, '[i]n Khorev (...) seeing correctly or being blinded by appearances-whether intentionally or not-emerges as one of the fundamental problems of being a good ruler'.25 As it was customary for early modern drama, Sumarokov's construction of tragic plot and characters resonated with what Benjamin describes as Machiavellian political anthropology, produced and disseminated across Europe by innumerable treatises, avidly read and oftentimes translated in early eighteenth-century Russia. ${ }^{26}$ Among the works which have survived in these never published and barely studied manuscript translations is Diego de Saavedra Fajardo's emblematic treatise Idea de un príncipe político

25 Levitt, The Visual Dominant in Eighteenth-Century Russia (DeKalb: Northern Illinois University Press, 2011), 95-96.

26 On 'political anthropology' at the core of early modern tragedy, see Benjamin, The Origin of German Tragic Drama, p. 100; Alain Viala, 'Péril, conseil et secret d'État dans les tragédies romaines de Racine: Racine et Machiavel', Littératures classiques 26 (1996), 91-113. On early eighteenth-century Russian translations of European political literature, see M.A. Iusim, Makiavelliv Rossii. On the spread and development of Machiavellian politics of 'reason of state' see Friedrich Meinecke, Die Idee der Staatsräson in der neueren Geschichte (Stuttgart: Koehler, 1963) (= Friedrich Meinecke, Werke, Bd. 1). 
cristiano (1640) widely known in Europe and rendered into Russian on the personal orders of Elizabeth's father, the reforming tsar Peter the Great (r. 16821725). One of Saavedra Fajardo's emblems, instructing the ruler to 'think always he may be deceived', shows a boat stern (korma, the position of Sumarokov's 'pilot' or 'helmsman', kormschik) and explains that a prince should not

be too positive in his opinions, but believe that he may easily be deceiv'd in his Judgment, either through Affection, or Passion, or false Information, or Flattery, and Insinuation ... because few things are really what they appear, especially in Policy, which is nowadays nothing but the art of cheating, or not being cheated; wherefore they ought to be viewed in different lights, and a Prince ought carefully to consider and weigh them not slightly to pass them over, least he should give credit to appearances and groundless stories ... How often have Waves of Envy and Jealousy been interpos'd between the Eyes of the Prince, and the Minister's actions, making those appear crooked and disloyal which are drawn by the rule of Justice and his Service. Thus Virtue suffers, the Prince loses a good Minister, and Malice triumphs in its Practices; which that he may practically know, and not suffer Innocence to be wrong'd, I will here set down the most usual. ${ }^{27}$

Discourse of this kind was immediately relevant for post-Petrine court politics. The fall of Artemii Volynskii was precipitated by a letter he wrote in 1739 to Empress Anna, masking an attempt to discredit his enemies at court as a generalized analysis of 'which ruses and stratagems are employed at your royal courts, and what all this secretive and shameless politics is about':

To conceive as much as possible harmful intrigues against the conscientious, to smear and discredit all their good deeds in order to bereave them of enthusiasm and service zeal. To instill doubt into sovereigns so that they would not believe anyone and all would be tainted with suspicion and would seem unworthy of favor; and sometimes suggest danger on occasions which can be appropriately seen as trifles, exaggerating them ... and then to recommend oneself to remedy or appease the said occasion, as if no one else could be trusted or at least no one has enough wisdom to overcome the supposed difficulties. In truth, however, the design of those

27 Diego de Saavedra Fajardo, Royal Politician Represented in One Hundred Emblems (London:

Matt. Gillyflower and Luke Meredith, 1700), vol. 1, pp. 319-320, 322. 
politicians or, to put it simply, cheats is to acquire favor with the sovereign through the said means, and to show their supposedly superior and true loyalty and zeal, even if there is nothing to worry about. Through this dishonest conduct a sovereign can be brought to such a state of mind that he eventually would be deceived (however wise he is) and would think that all of it is true what they tell and report him, and will be compelled to yield and on all occasions to follow the advice of the said politician, thinking: 'who else would I believe if no one else has either loyalty or zeal' .$^{28}$

Khorev's tragic plot is shaped by this sinister vision of courtly ways. Sumarokov's long-time opponent Vasilii Trediakovskii noted in his lengthy and insightful discussion of the dramatist's oeuvre that Khorev has two main plotlines: the love story, and 'Kii's suspicion of a supposed conspiracy between Khorev and Osnelda'. ${ }^{29}$ This suspicion, based on malicious exaggeration, is provoked by Stalverkh in the course of what might be seen as a courtly intrigue against a powerful general and a member of the royal family: Khorev complains to Kii that someone 'prezhnei milosti tvoei menia lishil' ('has deprived me of your former favor', II, 2, p. 25). Kii is well aware of the dangerous powers of envy outlined by Saavedra and Volynskii (he even voices the possibility that the charges are 'a deception' designed by the guards 'to ruin the innocent Khorev', IV, 3, p. 52) and is bent on resisting them, but eventually succumbs to a malicious reading of Khorev's intentions. Once admitted, the assumption that no one 'can now be trusted' undermines Kii's belief that his true subjects 'showed to me their inner selves', and erases the very possibility of recognizing true loyalty and distinguishing it from pretense.

In Benjamin's terms, Stalverkh incorporates the type of the intriguer who possesses 'a mastery of the workings of politics' based on anthropological insights and 'corresponds to an ideal which was first outlined by Machiavelli and which was energetically elaborated in the creative and theoretical literature of the seventeenth century'. In tragic drama, this intriguer is 'the organizer of the plot':

In all circumstances it was necessary for the intriguer to assume a dominating position in the economy of the drama. For according to the theory

28 RGADA, f. 6, op. 1, No 195, l. 8-9ob.

29 V.K. Trediakovskii, 'Pis'mo, v kotorom soderzhitsia rassuzhdenie o stikhotvorenii, ponyne na svet izdannom ... pisannoe ot priiatelia k priiateliu', in A.M. Ranchin and V.L. Korovin (eds.), Kritika XVIII veka, (Moscow: Olimp, 2002), pp. 29-108, here p. 100. 
of Scaliger, which in this respect harmonized with the interests of the baroque and was accepted by it, the real purpose of the drama was to communicate knowledge of the life of the soul, in the observation of which the intriguer is without equal. ${ }^{30}$

Duplicating the theatricality of the play itself, Stalverkh exposes Kii and the play's audience to a 'political anthropology' which views political practice as self-interested playacting. It is thanks to this anthropology that Stalverkh's hypothetical representation of the supposed conspiracy, which dangerously departs from truth, can achieve 'probability' prescribed for tragic plots by Aristotelian theory. As the true author of the plot-in the double sense of a political conspiracy and a set of fictional events-which makes Khorev a tragedy, Stalverkh follows a procedure similar to the one suggested in the Poetics for dramatic compositions. Dacier expressly derived the Aristotelian requirements for the 'probability or necessity' of represented action from the secretiveness of courtly politics, the arcana imperii:

a prodigious number of things happen every day, of which we know not the causes, especially those which concern Monarchs, which are properly the Subjects of Tragedy. Now a Poet is obliged to explain all the Causes of the Incidents which enter into the Composition of the Subject; and 'tis just to let him be Master of his Matter, so it should not be required of him to speak things as they are, but as they may, provided he follows either Necessity of Probability; for nothing more can be required of him. ${ }^{31}$

Just as a tragedian-like Sumarokov himself-is invited to inscribe the received plots, in fact fragmented accounts of political events, into a hypothetical set of probable motivations, the denunciator Stalverkh uses an overheard conversation between Osnelda and Khorev, indeed replete with dangerous ambiguities ('Befriend Zavlokh' - I will raise to the throne your royal blood again ... having once obtained this land's possession'), to construct a narrative of a conspiracy in progress which can be accepted as plausible by courtly audiences both in Kiev of the dramatic legend and eighteenth-century Petersburg.

In the political idiom of Saavedra's treatise and Volynskii's letter narratives of this kind are dismissed as malicious lies of evil councilors. While Sumarokov's Stalverkh seems to illustrate this logic, a closer look at his actions suggests a

30 Benjamin, The Origin of German Tragic Drama, pp. 95, 98-99.

31 Aristotle's Art of Poetry, p. 141; cf. La Poétique d'Aristote, p. 135. 
less straightforward — and even more disturbing — view of royally sponsored repression. Identifying Stalvekh with the type of the intriguer, Trediakovskii ridicules him for the lack of appropriate slyness:

Stalverkh ... is nothing but a very foolish slanderer. What cunning intriguer ... would smear someone who holds all the power in his hands when it is both impossible to harm him in any way and very probable that he can immediately take revenge when he finds out? And has ever slander stayed in secret? ${ }^{32}$

In fact, however, nowhere in the play do we find an unambiguous proof of Stalverkh's malicious intent. His final suicide ('Half-maddened with remorse ... remembering Osnelda') might be construed as a sign of his secret passion for the captive princess, which would explain his wish to prevent a peace agreement with Zavlokh and to smear Khorev, but it could also be seen simply as a symptom of remorse for the death of an innocent victim. The uncertainty regarding Stalverkh's personal motives fits well with his position of a subordinate character, a function rather than a personality. Even more overtly than others, 'Stalverkh, the first boyar of Kiev' is an allegory: his high rank forms the substance of his name, stal-verkh, almost precisely translated as 'upstart' and emphasizing his debt to service hierarchies rather than royal status or extraction enjoyed by the play's other principal characters. As an allegory, Stalverkh - who has an unblemished service record ('You have been true to me, Stalverkh') - is able to incorporate at once 'the two faces of the courtier: the intriguer, as the evil genius of their despots, and the faithful servant ${ }^{33}$ Whether or not his actions are driven by malice is not important: what matters is his mode of operation imbedded in the absolutist structure of power.

E.A. Kasatkina has identified Stalverkh's denunciation of Khorev as the principal motor of the play's tragic plot and linked it to the political trials of the $1730 \mathrm{~s}$ and 1740 s and the common practice of 'unverified denunciation. ${ }^{34}$ Indeed, political trials - alongside triumphal theatrical festivities-in largely overseen ways shaped the 'scenario of power' enacted during the first years of Elizabeth's rule. The allegations raised against Khorev by Stalverkh must have reminded Russian audiences of the hasty trial over the charismatic and popular Field Marshal Münnich, presided by the empress in early 1742 , in the first months

32 Trediakovskii, 'Pis'mo ... ot priiatelia k priiateliu', pp. 98-99.

33 Benjamin, The Origin of German Tragic Drama, p. 98.

34 Kasatkina, 'Sumarokovskaia tragediia 40-kh—nachala 50-kh godov XVIII veka', p. 216. 
after her ascension. Along with other high-ranking officials of the previous reign Münnich was found guilty of treason and sentenced to death, commuted to exile. This was followed in 1743 by the trial over Natalia Lopukhina and several other courtiers charged with political conspiracy allegedly driven by resentment in the wake of the previous trial. In these notorious trials as well as in the records of more trivial cases of seditious gossip constantly investigated and persecuted by the Secret Chancery the horror scenario of a political conspiracy surfaced time and again.

In Stalverkh's version of events Khorev, in order to overthrow Kii, conspired with a foreign ruler, Zavlokh, and simultaneously attempted to incite local troops to treason and revolt. Similarly, in the early 1740 s there was constant gossip that Elizabeth's overthrown predecessor Anna Leopoldovna might be restored to power both by disenchanted Petersburg guards and by the armed forces of her royal relatives, the kings of Prussia and Denmark and the Empress Queen Maria Theresa. ${ }^{35}$ The official narratives behind the two trials concluded by public acts of punishment on the scaffold and publicized through special royal manifestoes were as problematic as Stalverkh's. One memoirist claims that Münnich and his fellow defendants 'could easily have disproved these accusations, had their defense been listened to; but their condemnation was determined on'. Reflecting upon Lopukhina's trial another informed memoirist concludes that 'however we approach this case, we must admit that there was no apparent conspiracy'. ${ }^{36}$

While the highly publicized political trials were little more than 'legal fictions', invented stories whose effect on their audiences overshadowed the fragility of their truth claim, Sumarokov centered his dramatic fiction around a full-scale political trial over Osnelda, closely linked to Elizabethan judicial practice. The notorious system of political surveillance and persecution known as slovo i delo gosudarevo (literally, 'sovereign's word and deed') was designed to bring any cases of possible lese-majesty to the attention of the Secret Chancery and the sovereign. While recognizing the dangers of slander and threatening slanderers with the worst punishments, royal decrees time and again pro-

35 M.I. Semevskii, 'N.F. Lopukhina', Russkaia starina, 11 (1874), 9-10; M.I. Semevskii, 'Tainaia kantseliariia v 1741-1761 gg., Russkaia starina, 12 (1875), 533-537. For a wealth of similar material, and for the following discussion of judicial practices, see two recent monographs: Anisimov, Dyba i knut; Elena Nikulina and Igor Kurukin, Povsednevnaia zhizn' tainoi kantseliarii XVIII veka (Moscow: Molodaia gvardiia, 2008).

36 Christoph Hermann von Manstein, Contemporary Memoirs of Russia from the Year 1727 to 1744 (London: Longman, Brown, Green, and Longmans, 1856), p. 330; Perevoroty i voiny, p. 487. 
claimed political denunciations a sacred duty of any subject and servitor. Among the offences imputed to Volynskii after he sent his letter to Empress Anna was his equivocal manner of speech: censuring his enemies at court without naming them, he was either smearing the innocent or concealing crimes which he was obliged to openly denounce.

Against this background Stalverkh's denunciation seems a natural course of action for a high-standing official. The prosecution of Lopukhina was initiated by Elizabeth's confidant and personal surgeon Lestocq, who brought the supposed conspiracy to the empress's attention and arranged her personal meeting with an informer, inciting her to quick persecution. ${ }^{37}$ Similarly, Stalverkh reported the conversation between Khorev and Osnelda to Kii and confirmed his testimony with that of a 'captive' who had served as a messenger between Osnelda and Zavlokh; as a reward for incriminating the princess Kii set him free. Stalverkh thus triggered a formal legal inquiry personally presided by the prince, as was often the case in eighteenth-century Russia. In cases of lese-majesty and treason, suspicion, podozrenie, was recognized as sufficient grounds for persecution, revealing, as Evgenii Anisimov puts it, 'the sovereign's unlimited right to punish and pardon', 'the sovereign will of the autocrat as the ultimate source of law'. ${ }^{38}$ Petzold, a Saxon representative in Petersburg, gave the following account of Lopukhina's trial conducted under Elizabeth's royal supervision:

After their arrest the accused had voluntarily admitted everything that they knew. But since those utterances did not extend beyond ... general displeasure with the empress's way of life and a wish to see the restoration of the previous government ... [the prosecutors], basing on the assumption of a certainly existing conspiracy, were not satisfied with this, and asked first the young Lopukhin whether he knew of other accomplices and planned assaults. The empress was present personally, and ignored all the wailing and begging at her feet ... Lopukhina and Bestuzheva, as they were raised on the beams with their arms broken insisted most movingly that they could be torn to pieces but will never slander themselves or admit more than they know or have done. ${ }^{39}$

37 Semevskii, 'N.F. Lopukhina', p. 6.

38 Anisimov, Dyba i knut, p. 52 .

39 Sbornik Imperatorskago Russkogo istoricheskogo obshchestva, vol. 6 (Saint-Petersburg 1870), pp. 497-498. 
After Kii recognizes the legal implications of Stalverkh's report (II,1) — 'dnes' nad bratom mne byt' sudieiu dolzhno' (20, 'Today I will have to be the judge over my brother') - he deals with Osnelda in a scene (IV, 7) which represents nothing less than a royal interrogation, and in significant points resembles Lopukhina's trial. Osnelda, now a prisoner rather than a captive, is brought to the stage in irons. Kii confronts her with the false charge of conspiracy and treason, based on witness testimony, and attempts to extort a confession of guilt, acknowledged in the Petrine judicial code, the Kratkoe izobrazhenie protsessov ili sudebnykh tiazheb of 1716 , as 'the best testimony in the world'. Osnelda, frightened that Khorev might 'remain under suspicion', 'v podozrenii ostanetsia', admits to their mutual love and to their correspondence with Zavlokh but persistently denies any thought of treason, resorting to the only proof of innocence she can produce: the oath ('Klianusia vsem chto est', chto ia ne litsemeriu') which, according to Petrine law, could suffice for a requital. Kii counters this defense by demanding to see Zavlokh's letter that she has already burned; in legal terms it would have been qualified as written proof, 'pismennoe svidetel'stvo'. Moreover, he produces a charge she cannot refute: she said something inappropriate about his royal person, an evident case of lese-majesty, specifically identified in Peter's 1716 Artikul voinskii and other legal acts as a crime punishable by death. Osnelda has to admit to it, and Kii, who is generally aware of the advantages of clemency in a 'just trial' ('Shchedrota khvalitsia na pravednom sude') feels compelled in this case to fulfill his 'duty', passing a death sentence upon Osnelda: 'Umri, obmanshchitsa!' ('You die, deceitful wretch!' 56-63; transl. $74-78) \cdot{ }^{40}$

Kii's conviction of Osnelda, his most important royal act and the play's primary peripeteia, at once a coup de théâtre and a coup d'état, represents a point where theatrical representation, more specifically the dramatic idiom of tragic drama, is alone capable of providing insight into the workings of absolutist power. Benjamin has established that the fundamental affinity between tragic drama and political theory was rooted in the vision of sovereignty 'which takes as its example the special case in which dictatorial powers are unfolded'. This vision, famously revived and explored by Carl Schmitt and later Louis Marin, was developed in Machiavelli's wake by seventeenth-century political thinkers such as Gabriel Naudé and Cardinal Richelieu, whose works were read

40 Polnoe sobranie zakonov Rossiiskoi imperiis 1649 g., ([Saint-Petersburg], 1830) vol. 5, pp. 394, 400 sqq., 325 ( $\left.\mathrm{N}^{\circ} 3006\right)$. On policies encouraging denunciations see Elena Nikulina and Igor Kurukin, Povsednevnaia zhizn', pp. 158-175; on laws regarding lese-majesty and treason, and personal royal involvement in the persecution, see Anisimov, Dyba i knut, pp. 50-57, $95^{-123}$. 
and translated in eighteenth-century Russia, and revolved around the notion of coup d'état, which had a broader meaning than today's usage would suggest and often referred to violent persecution of the enemies of the state and crown. Consequently, Benjamin continues, ' $[t]$ he drama makes a special point of endowing the ruler with the gesture of executive power [die Geste der Vollstreckung], and having him take part in the action with the words and behavior of a tyrant even where the situation does not require it'. On the other hand, drama constantly shows the prince to be 'almost incapable of making a decision', thus revealing a fundamental 'antithesis between the power of the ruler and his capacity to rule. ${ }^{41}$

Addressing in his intricate, almost self-contradictory defense of autocracy the major threats inherent in monarchy, Tatishchev admitted the inevitable deficiency of a single ruler who would be at best 'wise, just, mild and diligent' but not 'free from faults', or worse, 'would give free reign to his passions', which would inevitably lead to 'unjust violence and ruin of the innocent'. Similarly problematic is the institution of councilors ('sovetniki') or favorites ('vremenshchiki') created to correct the flaws of monarchy but itself easily abused by someone who 'out of envy inflicts ruin on others ... especially persons of distinction and merit'. Finally, 'the evil and impious' can usurp the royally sanctioned powers of the secret police designed 'for the safety of the monarch' and invested with the right to inflict torture and death 'for a single carelessly uttered word' ${ }^{42}$ All these issues are reenacted in the catastrophe of Sumarokov's play: judicial abuse brought about by deceitful council highlights the troubling incapacity of the solitary ruler. In the play's finale Kii himself recognizes the self-destructive implications of his injustice and in a fit of a remorse pledges the victorious Khorev to 'cast me from the throne' (84), thus calling for the palace revolution anticipated by Stalverkh.

A monarch's tragic failure must not take the form of Hamletian inaction, emphasized in most readings of Benjamin, but may also emerge as its opposite-decisive action. Any royal act risks missing the elusive middle ground between the only seemingly opposed vices of weakness and excessive force, upsetting the precarious balance prescribed by Machiavelli. The new prince:

ought to be slow in giving credit to reports, not overhasty in his proceedings, and to beware of frightening himself with phantoms of his own rais-

\footnotetext{
41 Benjamin, The Origin of German Tragic Drama, pp. 69-71.

42 Tatishchev, 'Proizvol'noe i soglasnoe rassuzhdenie ... o pravlenii gosudarstvennom', in id., Sobranie sochinenii, vol. 8, pp. 149.
} 
ing; tempering his mercy with prudence in such a manner, that too much confidence may not put him off his guard, nor causeless jealousies make him insupportable. ${ }^{43}$

In a well-intended but futile pursuit of this golden mean Kii is trapped in constant chaotic oscillation between the extremes, as Trediakovskii reveals in his assessment of the character:

As for Kii, his indifference is quite awkward: the Author represents him as good-tempered at one moment and as ill-tempered at the next; at one moment he is a kind man, at the other extremely wicked. This Kii resembles a weather vane: wherever the wind blows, he turns in the same direction. In short, the Author's Kii is a perfect hypochondriac, or a kind of madman. ${ }^{44}$

Trediakovskii's analysis resonates both with Benjamin's discussion of murderous insanity as 'characteristic of the idea of the tyrant' in early modern drama, ${ }^{45}$ and with historical experiences of monarchy in eighteenth-century Russia. Volynskii, for example, argued in 1740 that while Empress Anna ought to judge with 'mercy and terror' ('nadobno ei sud s grozoiu is milostiiu imet'), she in fact 'sometimes becomes angry I do not even know for what reason', and generally 'there is nothing worse in a state than inconstancy, and in sovereigns, secrecy'46 In 1730 Empress Anna excused her past disfavor for the Spanish ambassador Duke of Liria by explaining to him 'that is was such a critical time that she did not know who is her friend or enemy, and was compelled to believe everything some people said about me and others. ${ }^{.47}$ Unlimited and unwarranted trust of some and mistrust of others, as well as the inconstancy of both enacted in Anna's very speech act, instead of debilitating the monarchy propelled it to regular acts of repression. It is in the Machiavellian idiom of court politics that we find an answer to the rhetorical question which the critic A. Gruzintsov asked to outline the tragic effects of Sumarokov's play and, specifically, the sentencing of Osnelda as one of Khorev's truly tragic scenes:

\footnotetext{
43 The Works of Nicholas Machiavel, 625.

44 Trediakovskii, 'Pis'mo ... pisannoe ot priiatelia k priiateliu', p. 98.

45 Benjamin, The Origin of German Tragic Drama, p. 69.

46 'Zapiska o Volynskom', Chteniia v Obshchestve istorii i drevnostei rossiiskikh, 1858, otd. 2, p. 149 .

47 Zapiski diuka Liriiskago i Bervikskago vo vremia prebyvaniia ego pri imperatorskom rossijskom dvore ... (Saint-Petersburg 1845), p. 111.
} 
what I do not understand is why Kii is so credulous; why is he so cruel that he ordered to poison Osnelda, who did him no harm, before the battle was over? and, what is even more unjust, he showed himself a tyrant through Osnelda's death without any reliable proof of his brother's treason (...) Does not this barbaric act appall all spectators? Does not Kii's action make him vicious in the eyes of the world? ${ }^{48}$

False charges brought against the main characters drive Khorev's plot, putting into question the legal procedures which seem to corroborate them, and, finally revealed as little more than 'legal fiction', provide a nucleus for the tragic fiction which is Sumarokov's play. Indeed, the affinity between Khorev and the judicial practice of Elizabethan Russia is not a matter of incidental topical allusion, but rather a symptom of the fundamental issues inherent in tragedy as a genre. Aristotle's definition of a tragic catastrophe hinges on the problematization of guilt and retribution: since pity is aroused 'by the Misfortunes of those who are like ourselves' and fear 'from the Miseries of those who deserve better Luck', the best tragic character is someone 'who is become miserable, by some involuntary fault' and not as a result of 'a Remarkable Crime'.49 The tragic effect is shaped by the mysteries of (in)justice, the discrepancy between crime and punishment.

\section{Theater of Compassion}

Sumarokov's dramatization of Osnelda's demise for court performances could have resonated with the spectacular finale of Lopukhina's trial, the public punishment of convicts on a scaffold - designated in official sources as 'theater' ('teatr') - in August 1743. ${ }^{50}$ This event made such an impression on the Russian public that the French astronomer Chappe D' Auteroche who visited Petersburg eighteen years later, in $1761-1762$, was able to give a vivid and detailed description of it in his travelogue:

Young, lovely, admired and sought after at court, of which place was the life and spirit; instead of the number of admirers her beauty usually drew after her, she then saw herself surrounded only by executioners (...) she

48 A. Gruzintsov, 'Ekzamen 'Khoreva”, Novosti literatury, 4 (1802), pp. 157-158.

49 Aristotle's Art of Poetry, pp. 186-187.

50 Semevskii, 'N.F. Lopukhina', pp. 193; for contemporary accounts of the trial, see Semevskii, 'N.F. Lopukhina. 1699-1763. Epizod iz eia zhizni', Russkii vestnik, 29 (1860), kn. 17. 
turned pale, and burst into tears: her clothes were soon after stripped off, and in a few moments she was quite naked to the waist, exposed to the eager looks of a vast concourse of people profoundly silent (...) in a few moments all the skin of her back was cut away in small strips, most of which remained hanging to the shift. Her tongue was cut out immediately after, and she was directly banished into Siberia. ${ }^{51}$

Chappe's account is invested with literary appeal achieved, one might argue, with means akin to those employed by Sumarokov. If in Khorev the royal prosecution of a jeune première becomes a source of aesthetic pleasure, Chappe's punishment scene reveals the workings of this standard yet paradoxical reaction: the audience of the execution, replacing the multitudes of Lopukhina's earlier 'admirers', takes erotic satisfaction in her nudity, submission and physical suffering. This pleasure, conveyed from the immediate eye witnesses to Chappe's readers, does not, however, imply a straightforward approval of the judicial procedure behind the punishment. Appealing to the conflicted sensibility of the audience, it molds a fascination for suffering with a compassion for the victim reminiscent of Aristotelian tragic 'pity'. In Racinian tragedy, as Roland Barthes remarks, 'disrobing' of the female self, including 'tears whose erotic power is so familiar', 'is always ... an attempt to compel pity (sometimes carried out to the point of sadistic provocation). ${ }^{52}$ In Sumarokov, a mixture of compassion and desire permeates Khorev's heavily eroticized, almost necrophilic, complaint after Osnelda's death $(\mathrm{v}, 4)$ :

Толь малодушным быть хоть мужу и не должно,

Но мысли горькия преодолеть не можно:

Оснельда во слезах пред очи предстает,

Которыя она о мне при смерти льет.

Воображаются мне все ея заразы ...

И представляются мне все утехи те,

Которых ожидал в драгой я красоте.

(Although a man must not be fainthearted,

I cannot overcome bitter thoughts.

51 Chappe D' Auteroche, A Journey Into Siberia: Made by Order of the King of France (London 1770), pp. 338-339. For a recent critical edition of Chappe's original, see id., Voyage en Sibérie: fait par ordre du roi en 1767, Édition critique par Michel Mervaud (Oxford: Voltaire Foundation, 2004), vol. 2, pp. 447-449. 
Osnelda comes to me, and she weeps,

Tears shed remembering our love even in death.

All her charms come back, as in a gentle daydream ...

And all the joys we sought, and all the joys we planned,

Which I expected from the beloved's beauty.)

85

As Zavlokh immediately makes clear, Khorev's grief provides a pattern for a public emotional response to Osnelda's demise:

Ты сделала, о дщерь! хотя упал наш трон, И победителям и побежденным стон.

И если в аде глас Хоревов дух твой тронет, Ликуй что по тебе Герой великий стонет, Уж не почтет тебя невольницею ад, Заплачет по тебе с Хоревом весь сей град.

75

(Although our throne is lost, $\mathrm{O}$ daughter, you have brought Conquered and conqueror past limits of despair. And if into the depths a prince's sobs may reach you, Rejoice! a hero weeps for that he truly loved you. The dusky lands you tread will judge you freed at last, For all the city mourns your loss with Prince Khorev.)

85

In the play's conclusion, Zavlokh's lines provide a blueprint for the emotional effects of tragedy itself, and Khorev in particular, as they outline the function that 'tragic' compassion is meant to assume both in Sumarokov's Kiev and at Elizabeth's court. Among its audiences Osnelda's death sets in motion a pattern of eroticized collective sensibility shared by the whole polity ('grad'). A fictionalized reenactment of political trials in the form of courtly entertainments certainly confirms Stephen Greenblatt's view that 'a dread bound up with the fate of particular situated individuals' was evoked in early modern drama (as well as in 'public maiming and executions' and royal pardons) because the ruling elites 'believed that a measure of insecurity and fear was a necessary, healthy element in the shaping of proper loyalties.' ${ }^{53}$ At the same time the medium of historical

53 Stephen Greenblatt, Shakespearean Negotiations: The Circulation of Social Energy in Re- 
drama produced a double distance — chronological and aesthetic - between stage action and the setting of its performance. While Osnelda's demise as the crux of tragic action stands for primeval brutality of the past, the emotional reaction it is calculated to produce in the audience is the opposite, one of mild compassion. Displacing the old emotional forms of domination, this mood (at least in Sumarokov's Kiev) expresses itself in public weeping and assumes a political function: it forges a novel emotional bond between ruler and subjects, 'conquered and conqueror'. Breaking with the 'masculine' and 'historical' hardheartedness styled as virtue, compassion for suffering emerges as a full-fledged 'aesthetic ideology', a new emotional paradigm of political coherence. ${ }^{54}$

This restoration of the political order depends on a reassessment of the royal role, fulfilled in Khorev's last scenes but prepared from the beginning of the play. If the execution of Osnelda is, according to Gruzintsov, a barbarian act which appalls 'all spectators' and presents Kii as 'vicious in the eyes of all the world', this perspective is not alien to Sumarokov's tragedy and its original context. In his discussion of the origins of government Tatishchev distinguished between two types of domination: the power of a conqueror ('preodoletel' ili khishchnik') who subdues his enemies with violence, and that of a 'true lord' ('suschii gospodin') who establishes his rule 'on the right of charity, like a father over his children', or on 'a voluntary compact.' ${ }^{55}$ Accordingly, the young Khorev, speaking for the polity his future spectators inhabit, lectures the old warrior Kii on virtuous rule and condemns 'brutishness under the guise of courage' which culminates in the lack of empathy at the sight of those in misery ('Nepopechitel'ny zria bednykh v gor'kom plache'-II, 2, l. 23). In a speech to Stalverkh Kii himself professes compassion (II, 1): 'Smushchaiusia, kak zriu ia i zlodeev v gore' (20, 'I am perplexed to see in grief even a villain', 55 ).

The compassionate royal gaze directed at the miserable and guilty, emphasized in Sumarokov's play, was institutionalized by court theater centered on tragedies. Assessing Sumarokov's achievement decades later, Nikolai Karamzin wrote that his tragedies were designed to 'draw tears from the eyes of the sensible Elizabeth. ${ }^{56}$ Indeed, Elizabeth — the first Russian monarch to make productions of tragedies a regular element of courtly life-made mournful compassion into an element of her royal role. After the death of her overthrown

naissance England (Berkeley and Los Angeles: University of California Press, 1988), pp.133138.

54 On 'aesthetic ideology' and eighteenth-century absolutism, see Terry Eagleton, The Ideology of the Aesthetic (Oxford: Blackwell, 1991), p. 19.

55 Tatishchev, 'Istoriia rossiiskaia', in id., Sobranie sochinenii, vol. 1, pp. 359-370, here p. 360.

$56 \quad$ N.M. Karamzin, Sochineniia (Leningrad: Khudozhestvennaia literatura, 1984), vol. 2, p. 112. 
rival Anna Leopoldovna in 1746 she had the corpse brought to Petersburg and, according to a semi-official account, displayed 'a greatness of spirit, exalted by the signs of humanity and compassion at the thought of the inconstancy of worldly things (...) when she wept at the funeral. ${ }^{57}$ Building on political and poetic visions of pity, Kii's final fit of compassion for Osnelda models the theatrical sensibility of the royal spectator-a new facet of Elizabeth's ambivalent 'scenario of power'.

In his preface to Aristotle, Dacier recounts the well-known anecdote about Alexander of Pherae, a Greek tyrant who had to leave a performance of a tragedy because 'he was asham'd to be seen to weep, at the Misfortunes of Hecuba and Polyxena, when he daily imbrud his Hands in the Blood of his Citizens; he was afraid that his Heart should be truly mollify'd, that the Spirit of Tyranny would now leave the possession of his Breast'.58 Conversely, in Elizabethan Russia royal encouragement of national tragedy and court theater developed after the cessation of political trials (Lopukhina's was the last). Tragic theater affirmed the empress's new role as a compassionate ruler and re-enhanced her bond with her subjects through collective experiences of pity, while simultaneously upholding and reviving in public imagination the threats of royal terror.

\section{Conclusion}

In his recent discussion of Sumarokov's tragedies and their political resonances, Marcus Levitt maintains that 'Soviet attempts to read Russian classicist tragedy as politically oppositionist are misdirected; autocracy generally serves as the political context and not the target of Russian classicist tragedy.59 Indeed, Sumarokov vehemently insisted that his tragedies were written for the court rather than for private audiences, and already Khorev manifested the pervasive dependence of Russian tragedy as a cultural form on the institutional and symbolic resources of court theater. ${ }^{60}$ As I have noted in the beginning of this essay, Russian tragedy emerged as a paradox, a court entertainment

\footnotetext{
57 Portrait naturel de l'Imperatrice de Russie Glorieusement Régnante ... (Hambourg: s.d.), p. 6.

$5^{8}$ Aristotle's Art of Poetry, Preface.

59 Levitt, The Visual Dominant in Eighteenth-Century Russia, p. 118.

6o Pis'ma russkikh pisatelei XVIII veka (Leningrad: Nauka, 1980), 176. On Sumarokov's dependence on court patronage as a primary factor of social advancement see Levitt, "The Illegal Staging of Sumarokov's Sinav i Truvor in 1770 and the Problem of Authorial Status in Eighteenth-Century Russia', in id., Early Modern Russian Letters, pp. 190-217, 205-213.
} 
which revealed — under royal sponsorship and close supervision - the most horrifying aspects of the political order. Sumarokov's dramatic reenactments of royal spectacular injustice stood in an evident contradiction to the ubiquitous 'scenario of rejoicing' which, as Wortman has amply demonstrated, informed most official celebrations of Russian monarchy. I would argue, however, that instead of subverting the 'scenario of power' suggested by conventional panegyric forms (represented in this case by the Kievan masque) tragedy enhanced its sway by extending its emotional scope.

Along with the opera seria, tragedy belonged to an aesthetic of courtly ceremony and entertainment gradually adopted in Russia alongside other features of Western-type courts since the 1730s. This link was made clear in the very first essays on theater printed in Russian, which appeared in $1733^{-1738}$ in Russia's only journal, published by the court-sponsored Academy of Sciences. A lengthy 1738 essay on the history of the opera contained a detailed description of fetes held at different European courts since the Renaissance and praised the 'illustrious courts accustomed to magnificence, great luxury and solid view of things', among them the Russian court with its first opera productions, as primary spaces of cultural development. ${ }^{61}$ An earlier piece of the series, a 1733 essay on spoken drama, specifically addressed the paradox of the theatrical success of tragedies, 'which rather induce the spectators to grief than to joy'. Describing the genre with a literal translation of the German term 'Trauerspiel', 'mournful play' - 'pechal'naia igra' - the essay explained its prominence through a proto-Nietzschean analogy with the European-type music recently imported to Russia and also associated with the culture of the court: Tragedy is similar to musical dissonance, which, though itself unpleasant to the ear, in skillful combination with the pleasant consonances provides for more 'delight and admiration' than the consonances alone. ${ }^{62}$

Sumarokov interweaves this emotional palette, which adds grief to the Aristotelian pity and fear, into his dramatic fabric. Having learned that Osnelda reciprocates his feelings but apprehensive of her departure with Zavlokh, Khorev exclaims (I, 3):

О час! приятный час! но час и купно люты.

Какими я могу назвать твои минуты?

61 L.M. Starikova, ed., Teatral'naia zhizn' Rossii v epokhu Anny Ioannovny (Moskva: Nauka, 1995), 532-557, 560 .

62 'O pozorishchnykh igrakh, ili komediiakh i tragediiakh', in L.M. Starikova, ed., Teatral'naia zhizn' Rossii v epokhu Anny Ioannovny (Moskva: Nauka, 1995), p. 518. 
Безщастными почесть? мне много щастья в них.

За щастливы приять? что зляй минут мне сих!

(Sweet hour and cruel! You are to me both cruel and gentle!

What accents can define these moment of our lifetime?

Call them unhappy? Still much happiness they bring.

Shall we say happy? Ah! What hours have brought more grief?)

$5^{1}$

If Khorev's joy derives from his love for Osnelda, his grief stems from the recognition ofZavlokh's austere patriarchal authority which binds Osnelda and is unlikely to cede to the lovers' tender feelings. As A.N. Robinson has shown, the dynamic of emotional oscillation between joy and grief was central to Russian political drama since its beginnings in the seventeenth century, and was firmly associated with the dangerous unpredictability of royal will. ${ }^{63}$ This dynamic both stood for a subject's anxiety in the face of power, and underlay an aesthetic of representation suited to broadcast and affirm the ambiguous image of domination incorporated by Sumarokov's royal fathers, Zavlokh and Kii, conscientious monarchs and infanticidal tyrants.

It is this ambiguity of authority which defined the fundamental affinity of autocracy and tragedy as its reenactment. As Benjamin demonstrates, kingship was simultaneously associated with 'the ideal of complete stabilization (...) continuity of the community, flourishing in feats of arms and the sciences', and with the opposing 'idea of catastrophe', the state of emergency which 'positively demands the completion of the image of the sovereign, as tyrant.' ${ }^{64}$ Similarly, Greenblatt concludes in his discussion of Shakespearean stagings of kingship that

the enhancement of royal power is not only a matter of the deferral of doubt: the very doubts that Shakespeare raises serve not to rob the king of his charisma but to heighten it, precisely as they heighten the theatrical interest of the play; the unequivocal, unambiguous celebrations of royal power with which the period abounds have no theatrical force (...) Within this theatrical setting, there is a notable insistence upon the paradoxes,

\footnotetext{
63 O.A. Derzhavina, A.S. Demin, and A.N. Robinson, 'Rukopisnaia dramaturgiia i teatral'naia zhizn' pervoi poloviny Xviı v.', in P'esy liubitelskikh teatrov (Moscow: Nauka, 1976), p. 95.

64 Walter Benjamin, The Origin of the German Tragic Drama, pp. 65-66, 69.
} 
ambiguities, and tensions of authority, but this apparent production of subversion is (...) the very condition of power. ${ }^{65}$

The 'tragic' oscillation between joy and grief apparently functioned as a poetic device designed to domesticate the collective experience of anxiety in its various emotional forms, integrating it into an affirmative ceremonial aesthetic. ${ }^{66}$ In Shakespeare's Hamlet King Claudius is introduced as he delivers a ceremonial speech asserting his recent succession to his deceased brother's throne and marriage to Gertrude 'With mirth in funeral and with dirge in marriage, | In equal scale weighing delight and dole.' This pattern of public sensibility is evidently meant to contain the 'private' political resentment of the likes of Hamlet, which takes the form of 'obstinate condolement' of the late king. ${ }^{67}$ If in Shakespeare this pattern of quasi-ritual containment is discredited together with the king and his 'rotten' realm, it was still upheld by eighteenth-century court tragedy and Sumarokov in particular. In Gamlet (1748), his second tragedy loosely yet manifestly modeled on Hamlet, it is voiced by a sympathetic figure, Ophelia's confidant Flemina who consoles her mistress after she learned of her father's crimes by elaborating on the benefits of misfortune:

Приятней солнца свет, когда пройдет ненастье, И слаще сладка жизнь, когда пройдет несчастье. Кто знает для чего случаи таковы (...)

(More brightly shines the sun after foul weather passes, And life seems sweeter in the wake of our misfortune. Who knows the purposes of happenings like this?) ${ }^{68}$

Flemina turns out to be right: Sumarokov's Prince is able to re-conquer his throne and can hope to marry Ophelia after she performs the proper 'mour-

65 Stephen Greenblatt, Shakespearean Negotiations: The Circulation of Social Energy in Renaissance England (Berkeley and Los Angeles: University of California Press, 1988), pp. 6365 .

66 Jörg Jochen Berns, Thomas Rahn, eds. Zeremoniell als höfische Ästhetik im Spätmittelalter und Früher Neuzeit (Tübingen: Niemeyer, 1995).

67 William Shakespeare, Hamlet, ed. by G.R. Hibbard (Oxford: Oxford University Press, 1987), 154-155, 160 (The Oxford Shakespeare); Michael Neill, Issues of Death: Mortality and Identity in English Renaissance Tragedy (Oxford: Clarendon Press, 1997), 300. I owe this reference to Susanne Wofford.

68 A.P. Sumarokov, Polnoe sobranie vsekh sochinenii (Moskva: V universitetskoi tipografii, 1787), vol. 3, p. 98; A.P. Sumarokov, Selected Tragedies, p. 118. 
ning duties' (to quote Shakespeare) for her criminal father. Fashioning political calamities, 'happenings like this', as Aristotelian peripeteia ('Peripetie is a change of one fortune into another'69), tragedy offered its spectators an emotional framework for, and an aesthetisised perspective on their very real experiences of anxiety and repression. Grief and misfortune are reinterpreted as a necessary source of royal triumph, produced—as visions of sovereignty rooted in the state of exception imply-in a cyclic scenario of eternal renovation. Accordingly, in royal drama the ceremonially affirmed emotional dynamic of grief and joy is refashioned as a source of aesthetic pleasure, just as it sets off and re-enhances the ostensible harmony of political cosmos.

\section{Further Reading}

Klein, Joachim, Puti kul'turnogo importa. Trudy po russkoi literature XvIII veka (Moscow: Iazyki slavianskoi kul'tury, 2005).

Ospovat, Kirill, Terror and Pity: Aleksandr Sumarokov and the Theater of Power in Elizabethan Russia (Boston: Academic Studies Press, forthcoming).

Wikander, Matthew H., Princes to Act:Royal Audience and Royal Performance, 1578-1792 (Baltimore, MD: Johns Hopkins University Press, 1993).

Wirtschafter, Elise Kimerling, The Play of Ideas in Russian Enlightenment Theater (DeKalb: Northern Illinois University Press 2003).

69 Aristotle's Art of Poetry, 162. 